\title{
Role of endogenous and exogenous ligands for the peroxisome proliferators activated receptors alpha (PPAR- $\alpha$ ) in the development of inflammatory bowel disease in mice
}

\author{
Salvatore Cuzzocrea ${ }^{1}$, Rosanna Di Paola ${ }^{1}$, Emanuela Mazzon ${ }^{1}$, Tiziana Genovese ${ }^{1}$, \\ Carmelo Muià ${ }^{1}$, Tommaso Centorrino ${ }^{2}$ and Achille P Caputi ${ }^{1}$ \\ ${ }^{1}$ Department of Clinical and Experimental Medicine and Pharmacology, School of Medicine, University of \\ Messina, Policlinico Universitario, Messina, Italy and ${ }^{2}$ Department of Surgical Specialities, School of \\ Medicine, University of Messina, Policlinico Universitario, Messina, Italy
}

\begin{abstract}
The peroxisome proliferator-activated receptor- $\alpha$ (PPAR- $\alpha$ ) is a member of the nuclear receptor superfamily of ligand-dependent transcription factors related to retinoid, steroid and thyroid hormone receptors. The aim of the present study was to examine the effects of endogenous and exogenous PPAR- $\alpha$ ligand on the development of experimental colitis. To address this question, we used an experimental model of colitis, induced by dinitrobenzene sulfonic acid (DNBS). When compared to DNBS-treated PPAR- $\alpha$ wild-type (WT) mice, DNBStreated PPAR- $\alpha$ knockout mice (PPAR- $\alpha$ KO) mice experienced a higher rate of the extent and severity of the histological signs of colon injury. After administration of DNBS PPAR- $\alpha \mathrm{WT}$ mice experienced hemorrhagic diarrhea, weight loss and large areas of necrosis in the mucosa of the colon were also observed. Neutrophil infiltration was associated with upregulation of ICAM-1. Immunohistochemistry for nitrotyrosine showed an intense staining in the inflamed colon. Absence of a functional PPAR- $\alpha$ gene in PPAR- $\alpha$ KO mice resulted in a significant augmentation of all the above-described parameters. On the contrary, the treatment of PPAR- $\alpha$ WT with Wy-14643 (1 mg/kg daily i.p) significantly reduced: (i) the degree of hemorrhagic diarrhea and weight loss, (ii) the degree of colon injury, (iii) the rise in MPO activity (mucosa), (iv) the increase in staining (immunohistochemistry) for nitrotyrosine, as well as (v) the upregulation of ICAM-1 caused by DNBS in the colon. In order to elucidate whether the protective effects of Wy-14643 is related to activation of the PPAR- $\alpha$ receptor, we also investigated the effect the of Wy-14643 treatment on PPAR- $\alpha$-deficient mice. The absence of the PPAR- $\alpha$ receptor significantly abolished the protective effect of the PPAR- $\alpha$ agonist against DNBS-induced colitis. Thus, endogenous and exogenous PPAR- $\alpha$ ligands reduce the degree of colitis caused by DNBS. We propose that PPAR- $\alpha$ ligand may be useful in the treatment of inflammatory bowel disease.

Laboratory Investigation (2004) 84, 1643-1654, advance online publication, 11 October 2004; doi:10.1038/labinvest.3700185
\end{abstract}

Keywords: PPAR-alpha; colitis; free radical; cytokines; inflammatory cell infiltration; PPARs

The inflammatory bowel diseases (IBD), Crohn's disease and ulcerative colitis have become important health problems in recent years. With an actual prevalence of 200-500 per 100000 people in Western countries and an incidence of about 20 per 100000 people, the prevalence in high incidence areas almost doubles every 10 years. Indeed,

Correspondence: Professor S Cuzzocrea, PhD, Department of Pharmacology, School of Medicine, University of Messina, via C. Valeria, Torre Biologica, Policlinico Universitario, 98123 Messina, Italy.

E-mail: salvator@unime.it

Received 14 June 2004; revised and accepted 11 July 2004; published online 11 October 2004 both are diseases of a lifetime, affecting people at a young age. In the last decade, there has been a shift towards more Crohn's disease in areas with a high incidence of IBD, and IBD has tended to occur at all ages. While this disease has a worldwide distribution, its pathogenesis is not clearly understood. ${ }^{1} \mathrm{~A}$ major advance in the study of IBD and one that provides strong support for the above concept has been the discovery and subsequent analysis of a number of models of mucosal inflammation that resemble IBD. ${ }^{2-4}$ Recently, Blumberg et $a l^{5}$ have indicated that these models fall into four main categories: spontaneous, administration of exogenous agents, gene targeting knockout or transgenic, transfer of cells into immunodeficient animals, and 
each provides unique opportunities to discover insights into the nature of the pathogenesis of IBD. Dinitrobenzene sulfonic acid (DNBS)-induced colitis in experimental animals (eg mouse and rats) has proven to be a useful model of IBD, as it possesses many of the cell and humoral immunity characteristics found in human IBD.,

Peroxisome proliferator-activated receptors (PPARs) are members of the nuclear hormone receptor superfamily of ligand-activated transcription factors that are related to retinoid, steroid and thyroid hormone receptors. ${ }^{8}$ All members of this superfamily have a similar structure: the amino-terminal (N-terminal) region allows ligand-independent activation, confers constitutive activity on the receptor and is negatively regulated by phosphorylation. This region is followed by a DNA-binding domain (two zinc-finger motifs separated by a linker region), and the C-terminal ligand-binding domain. ${ }^{9}$ The PPAR subfamily comprises of three members: PPAR$\alpha$, PPAR- $\beta$ and PPAR $-\gamma{ }^{10}$ The name PPAR is derived from the fact that activation by xenobiotics of PPAR$\alpha$ results in peroxisome proliferation in rodent hepatocytes. Activation of PPAR- $\beta$ or PPAR- $\gamma$, however, does not elicit this response. ${ }^{10}$ Most tissues in humans (and rodents) all three receptor subtypes, although there is considerable variability in the relative expression. PPARs regulate gene expression by binding, as heterodimers with retinoid $\mathrm{X}$ receptors (RXRs) to specific PPAR response elements (PPRE) in the promoter regions of specific target genes. RXRs are also members of the nuclear hormone receptor superfamily that are activated by binding of 9-cis-retinoic acid. ${ }^{11}$ In the absence of a ligand, high-affinity complexes are formed between the PPAR-RXR heterodimer and nuclear receptor corepressor proteins, preventing transcriptional activation by sequestration of the nuclear receptor heterodimer from the promoter. Binding of a ligand to the heterodimer results in the release of the corepressor from the complex, which in turn results in the binding of the activated heterodimer to the response element in the promoter region of the relevant target genes, resulting in either the activation or suppression of a specific gene. ${ }^{11}$ In rats, PPAR- $\alpha$ is most highly expressed in brown adipose tissue, followed by liver, kidney, heart and skeletal muscle. ${ }^{12}$ PPARs are expressed in the intestine at various levels. ${ }^{13-15}$ Recently, it has been also demonstrated that PPAR- $\alpha$ is also expressed in the digestive tract mainly localized in the intestinal mucosa in the small intestine and in the colon. ${ }^{13-15}$ In particular, it has been demonstrated that there is a higher expression of PPAR in the more differentiated colonic epithelial cells facing the intestinal lumen as compared to cells in the lower parts of the crypts. ${ }^{13}$

PPAR- $\alpha$ binds to a diverse set of ligands, namely, arachidonic acid metabolites (prostaglandins and leukotrienes) and plasticizers and synthetic fibrate drugs including clofibrate, fenofibrate and bezafi- brate. ${ }^{16}$ Given that no single high-affinity natural ligand has been identified for PPAR- $\alpha$, it has been proposed that a physiological role of the receptor may be to sense the total flux of dietary fatty acids in key tissues. Many PPAR- $\alpha$ ligands, including most of the common fibrate ligands, show only modest selectivity over the other PPAR subtypes. However, a potent thioisobutyric acid GW7647 has been identified that shows excellent selectivity for both murine and human PPAR- $\alpha .^{17,18}$ The recent development of a novel class of insulin-sensitizing drugs, the thiazolidinediones (TZDs), represents a significant advance in antidiabetic therapy.

There is now good evidence that the beneficial effects of TZDs are due to the activation of PPAR- $\gamma{ }^{19}$ The insulin-sensitizer rosiglitazone is the most potent and selective PPAR- $\gamma$ agonist ${ }^{20-22}$ and there is a good correlation between the potency of the TZDs as PPAR- $\gamma$ agonists in vitro and their efficacy at lowering glucose levels in vivo. ${ }^{23}$ There is recent evidence that PPAR- $\gamma$ agonists may also reduce the development of experimental colitis. ${ }^{24,25}$ On the contrary, the effects of PPAR- $\alpha$ agonists in conditions associated with experimental colitis have, however, not yet been investigated. The present study was designed to gain a better understanding of the role of endogenous PPAR- $\alpha$ ligands as well as the effects of Wy-14643 in rodent models of DNBS-induced colitis. In order to gain a better insight into the mechanism(s) of action of the observed anti-inflammatory effects of Wy-14643, we have also investigated the effects of $\mathrm{Wy}-14643$ on (i) the degree of colonic injury, (ii) the rise in MPO activity (mucosa), (iii) the production of tumor necrosis factor-alpha $(\mathrm{TNF}-\alpha$ ) and interleukin-1 $\beta$ (IL-1 $\beta$ ) (colon levels), (iv) the increase in staining (immunohistochemistry) for nitrotyrosine, as well as (v) the increased expression of ICAM-1 caused by DNBS in the colon.

Finally, in order to elucidate whether the protective effects of $\mathrm{Wy}-14643$ is related to the activation of the PPAR- $\alpha$ receptor, we have also investigated whether the treatment of PPAR- $\alpha$-deficient mice with Wy-14643 will exert similar protective effect.

\section{Materials and methods}

\section{Animals}

Mice (4-5 weeks old, 20-22g) with a targeted disruption of the PPAR- $\alpha$ gene (PPAR- $\alpha \mathrm{KO}$ ) and littermate wild-type controls (PPAR- $\alpha \mathrm{WT}$ ) were purchased from Jackson Laboratories (Harlan Nossan, Italy). Mice homozygous for the Pparat ${ }^{\mathrm{nij}}$ Gonz targeted mutation mice are viable, fertile and appear normal in appearance and behavior. Exon eight, encoding the ligand-binding domain, was disrupted by the insertion of a $1.14 \mathrm{~kb}$ neomycin resistance gene in the opposite transcriptional direction. After electroporation of the targeting construct into J1 ES cells, the ES cells were injected into C57BL/6N 
blastocysts. This strain was created on B6,129S4 background and is maintained as a homozygote on a 129S4/SvJae background by brother-sister matings. The animals were housed in a controlled environment and provided with standard rodent chow and water. Animal care was in compliance with Italian regulations on protection of animals used for experimental and other scientific purposes (D.M. 116192) as well as with the EEC regulations (O.J. of E.C. L 358/1 12/18/1986).

\section{Experimental Groups}

Mice will be randomly allocated into the following groups: (i) PPAR- $\alpha W T$ DNBS + saline group: PPAR$\alpha \mathrm{WT}$ will be subjected to DNBS-induced colitis plus administration of saline $(N=10)$; (ii) $P P A R-\alpha K O$ $D N B S+$ saline group: PPAR- $\alpha \mathrm{KO}$ will be subjected to DNBS-induced colitis plus administration of saline $(N=10)$; (iii) PPAR- $\alpha W T W_{y-14643}$ group: identical to the PPAR- $\alpha \mathrm{WT}$ DNBS + saline group but were administered Wy-14643 $(1 \mathrm{mg} / \mathrm{kg}$ dissolved in $10 \%$ ethanol i.p. bolus) which was given daily as an intraperitoneal (i.p.) injection starting $30 \mathrm{~min}$ after the administration of DNBS $(N=10)$; (iv) PPAR- $\alpha K O$ $W y-14643$ group: identical to the PPAR- $\alpha$ KO DNBS + saline group but were administered Wy14643 ( $1 \mathrm{mg} / \mathrm{kg}$ dissolved in 10\% ethanol i.p. bolus) which was given daily as an intraperitoneal (i.p.) injection starting $30 \mathrm{~min}$ after the administration of DNBS $(N=10)$; (v) PPAR- $\alpha$ WT Sham + saline: PPAR$\alpha \mathrm{WT}$ mice were subjected to the surgical procedures as the above groups except instead of DNBS $100 \mu \mathrm{l}$ of $50 \%$ ethanol were administered to the mice $(N=10)$; (vi) PPAR- $\alpha$ KO Sham + saline: PPAR- $\alpha$ KO mice were subjected to the surgical procedures as the above groups except that instead of DNBS $100 \mu \mathrm{l}$ of $50 \%$ ethanol were administered to the mice $(N=10)$; (vii) PPAR- $\alpha W T$ Sham $+W y-14643$ group: identical to PPAR- $\alpha \mathrm{WT}$ Sham + saline group except for the administration of Wy-14643 group and (viii) PPAR$\alpha \mathrm{KO}$ Sham $+\mathrm{Wy}-14643$ group: identical to PPAR$\alpha \mathrm{KO}$ Sham + saline group except for the administration of Wy-14643 group.

\section{Induction of Experimental Colitis}

Colitis was induced with a very low dose of DNBS ( $4 \mathrm{mg}$ per mouse) by using a modification ${ }^{26}$ of the method first described in rats. ${ }^{27}$ In preliminary experiments, this dose of DNBS was found to induce reproducible colitis without mortality. Mice were anesthetized by Enflurane. DNBS (4 mg in $100 \mu \mathrm{l}$ of $50 \%$ ethanol) was injected into the rectum through a catheter inserted $4.5 \mathrm{~cm}$ proximally to the anus. Carrier alone $(100 \mu \mathrm{l}$ of $50 \%$ ethanol) was administered in control experiments. Thereafter, the animals were kept for $15 \mathrm{~min}$ in a Trendelenburg position to avoid reflux. After colitis and sham-colitis induction, the animals were observed for 3 days. On Day
4, the animals were weighed and anesthetized with chloral hydrate, and the abdomen was opened by a midline incision. The colon was removed, freed from surrounding tissues, opened along the antimesenteric border, rinsed, weighed, and processed for histology and immunohistochemistry. Colon damage (macroscopic damage score) was evaluated and scored by two independent observers as described previously ${ }^{28-30}$ according to the following criteria: 0 , no damage; 1 , localized hyperemia without ulcers; 2, linear ulcers with no significant inflammation; 3, linear ulcers with inflammation at one site; 4, two or more major sites of inflammation and ulceration extending $>1 \mathrm{~cm}$ along the length of the colon; and $5-8$, one point is added for each centimeter of ulceration beyond an initial $2 \mathrm{~cm}$.

\section{Light Microscopy}

After fixation for 1 week at room temperature in Dietrich solution $(14.25 \%$ ethanol, $1.85 \%$ formaldehyde, $1 \%$ acetic acid), samples were dehydrated in graded ethanol and embedded in Paraplast (Sherwood Medical, Mahwah, NJ, USA). Thereafter, 7- $\mu \mathrm{m}$ sections were deparaffinized with xylene, stained with hematoxylin-eosin and trichromic van Giesson's stain, and observed in a Dialux 22 Leitz (Wetziar, Germany) microscope. In order to have a quantitative estimation of colon damage, section ( $n=6$ for each animals) was scored by two independent observers blinded to the experimental protocol. The following morphological criteria were considered: score 0, no damage; score 1 (mild), focal epithelial edema and necrosis; score 2 (moderate), diffuse swelling and necrosis of the villi; score 3 (severe), necrosis with presence of neutrophil infiltrate in the submucosa; score 4 (highly severe), widespread necrosis with massive neutrophil infiltrate and hemorrhage.

\section{Myeloperoxidase Activity}

Myeloperoxidase (MPO) activity, an indicator of polymorphonuclear leukocyte PMN) accumulation, was determined as previously described. ${ }^{31}$ At 4 days after intracolonic injection of DNBS, the colon was removed and weighed. The colon was homogenized in a solution containing $0.5 \%$ hexadecyltrimethylammonium bromide dissolved in $10 \mathrm{mM}$ potassium phosphate buffer ( $\mathrm{pH} \mathrm{7)}$ and centrifuged for $30 \mathrm{~min}$ at $20000 \mathrm{~g}$ at $4{ }^{\circ} \mathrm{C}$. An aliquot of the supernatant was then allowed to react with a solution of tetramethylbenzidine $(1.6 \mathrm{mM})$ and $0.1 \mathrm{mM} \mathrm{H}_{2} \mathrm{O}_{2}$. The rate of change in absorbance was measured spectrophotometrically at $650 \mathrm{~nm}$. MPO activity was defined as the quantity of enzyme degrading $1 \mu \mathrm{mol}$ of peroxide per min at $37^{\circ} \mathrm{C}$ and was expressed in milliunits per gram weight of wet tissue. 


\section{Measurement of Cytokines}

Portions of terminal colon, collected at 4 days after intracolonic injection of DNBS, were homogenized as previously described ${ }^{32}$ in PBS containing $2 \mathrm{mmol} /$ l of phenylmethyl sulfonyl fluoride (Sigma Chemical Co.) and tissue levels of TNF- $\alpha$ and IL-1 $\beta$ were evaluated. The assay was carried out by using a colorimetric, commercial kit (Calbiochem-Novabiochem Corporation, USA) according to the manufacturer's instructions. All cytokines determinations were performed in duplicate serial dilutions.

\section{Localization of nitrotyrosine, ICAM-1, TNF- $\alpha$ and IL-1 $\beta$ by immunohistochemistry}

Four days after the somministration of DNBS, the tissues were fixed in 10\% PBS-buffered formaldehyde and $8 \mu \mathrm{m}$ sections were prepared from paraffin embedded tissues. After deparaffinization, endogenous peroxidase was quenched with $0.3 \% \mathrm{H}_{2} \mathrm{O}_{2}$ in $60 \%$ methanol for $30 \mathrm{~min}$. The sections were permeabilized with $0.1 \%$ Triton X-100 in PBS for 20 min. Nonspecific adsorption was minimized by incubating the section in $2 \%$ normal goat serum in PBS for $20 \mathrm{~min}$. Endogenous biotin or avidin binding sites were blocked by sequential incubation for 15 min with avidin and biotin (DBA, Milan, Italy). Sections were incubated overnight with (1) antinitrotyrosine rabbit polyclonal antibody (1:500 in PBS), with anti-ICAM-1 polyclonal antibody (CD54) (1:500 in PBS, v/v) (DBA, Milan, Italy), with antiTNF- $\alpha$ polyclonal antibody (1:100 in PBS, v/v) or with anti-IL1- $\beta$ polyclonal antibody (1:100 in PBS, v/v) (Santa Cruz, DBA, Milan, Italy). Specific labeling was detected with a biotin-conjugated goat anti-rabbit, donkey anti-goat or goat anti-mouse IgG and avidin-biotin peroxidase complex (DBA, Milan, Italy). To verify the binding specificity for ICAM-1, TNF- $\alpha$ or anti-IL1- $\beta$, some sections were also incubated with primary antibody only (no secondary antibody) or with secondary antibody only (no primary antibody). In these situations, no positive staining was found in the sections indicating that the immunoreactions were positive in all the experiments carried out. In order to confirm that the immunoreactions for the nitrotyrosine were specific some sections were also incubated with the primary antibody (anti-nitrotyrosine) in the presence of excess nitrotyrosine $(10 \mathrm{mM})$ to verify the binding specificity.

Immunocytochemistry photographs $(N=5)$ were assessed by densitometry by using Optilab Graftek software on a Macintosh personal computer.

\section{Reagents}

Wy-14643 was obtained from Cayman Chemical (Inalco, Milan, Italy). Biotin blocking kit, biotinconjugated goat anti-rabbit IgG and avidin-biotin peroxidase complex were obtained from Vector Laboratories (Burlingame, CA, USA). Primary antinitrotyrosine antibody was purchased from Upstate Biotech (Saranac Lake, NY, USA). Primary ICAM-1 (CD54) for immunohistochemistry was purchased by Pharmingen. Reagents and secondary and nonspecific IgG antibody for immunohistochemical analysis were from Vector Laboratories Inc. All other reagents and compounds used were obtained from Sigma Chemical Company.

\section{Statistical Analysis}

All values in the figures and text are expressed as mean \pm s.e.m. of $n$ observations, where $n$ represents the number of animals studied. In the experiments involving histology or immunohistochemistry, the figures shown are representative of at least three experiments performed on different experimental days. Data sets were examined by one- and two-way analysis of variance and individual group means were then compared with Student's unpaired $t$-test. Nonparametric data were analyzed with the Fisher's exact test. A $P$-value less than 0.05 was considered significant.

\section{Results}

Effects of Endogenous and Exogenous PPAR- $\alpha$ Ligand on the Degree of Colitis (Histology and General Assessment)

At 4 days after intracolonic administration of DNBS, the colon appeared flaccid and filled with liquid stool. The macroscopic inspection of cecum, colon and rectum showed presence of mucosal congestion, erosion and hemorrhagic ulcerations (see damage score in Figure 1a). The histopathological features included a transmural necrosis and edema and a diffuse leukocyte cellular infiltrate in the submucosa of colon section from DNBS-treated PPAR- $\alpha$ WT mice (Figures $1 \mathrm{~b}$ and 2a). The observed inflammatory changes of the large intestine were associated with an increase in the weight of the colon (Figure $3 a)$. The absence of PPAR- $\alpha$ gene significantly increases the extent and severity of the histological signs of colon injury (Figures 1 and $2 \mathrm{~b}$ ) as well as the colon weight (Figure 3a). At 4 days after colitis induced by DNBS treatment, all mice had diarrhea and a significant reduction in body weight (compared with the control groups of mice) (Figure $3 \mathrm{~b}$ ). Absence of a functional PPAR- $\alpha$ gene in PPAR- $\alpha$ KO mice resulted in a significant augmentation of lost of body weight (Figure 3b). No histological alteration was observed in the colon tissue from vehicletreated PPAR- $\alpha \mathrm{WT}$ and PPAR- $\alpha \mathrm{KO}$ mice (Figure 2a, b, respectively). On the other hand, the treatment of PPAR- $\alpha$ WT with Wy-14643, a potent exogenous PPAR- $\alpha$ ligand, resulted in a significant decrease in the extent and severity of the injury of the large 

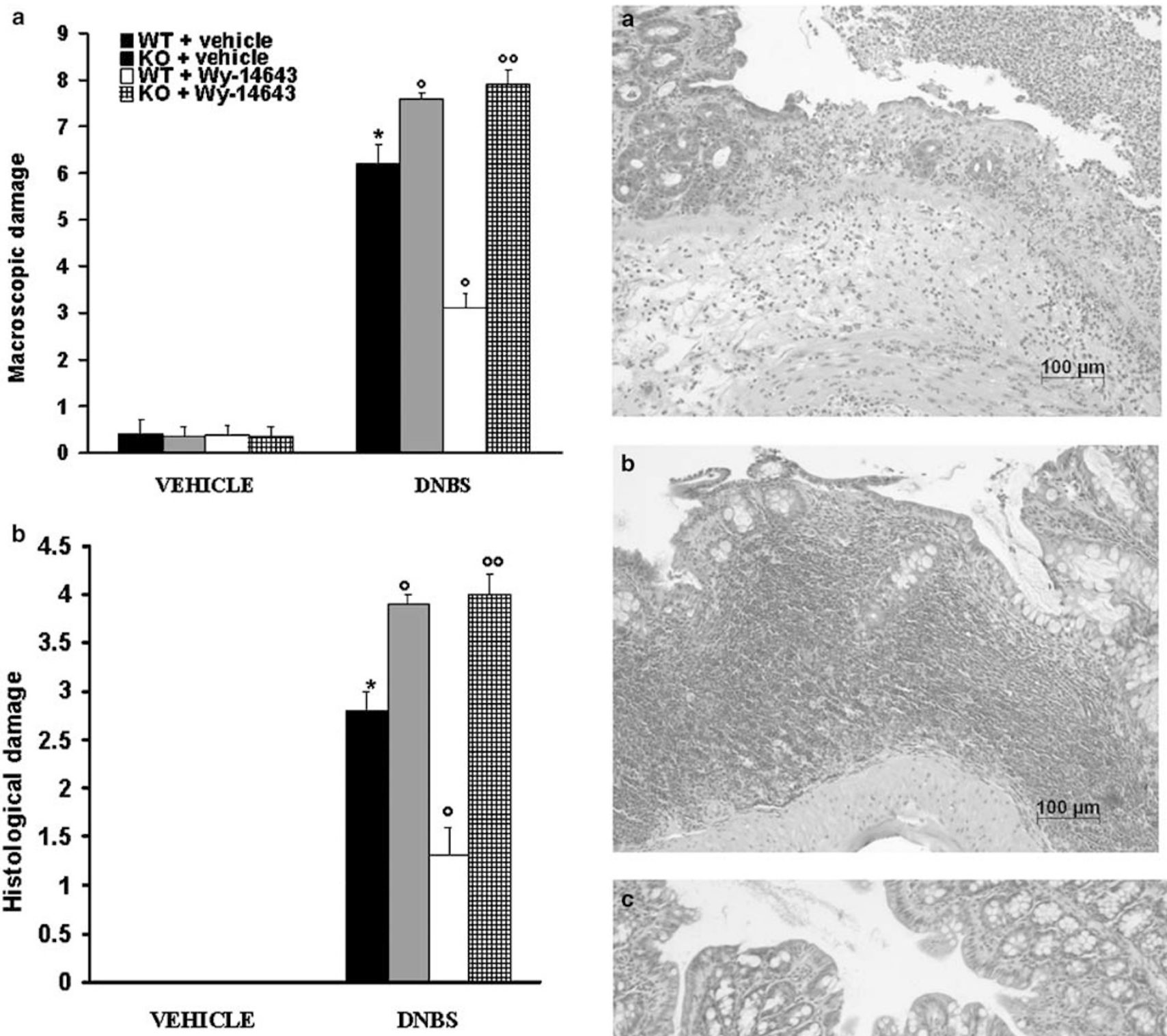

Figure 1 Effects of endogenous and exogenous PPAR- $\alpha$ ligand on the macroscopic damage score (a) and histological score (b). The macroscopic and histological score were made by two independent observers. Data are means \pm s.e.m. of 10 mice for each group. ${ }^{*} P<0.01$ vs SHAM; ${ }^{\circ} P<0.01$ vs DNBS; ${ }^{\circ} P<0.01$ vs DNBS-WT + Wy-14643.

intestine (Figures 1, 2c and 3). The genetic absence of the PPAR- $\alpha$ receptor significantly blocked the effect of the PPAR- $\alpha$ agonist (Figures 1 and 3).

\section{Endogenous and Exogenous PPAR- $\alpha$ Ligand Modulates Production and Expression of TNF- $\alpha$ and IL-1 $\beta$ after DNBS Administration}

To test whether endogenous and exogenous PPAR- $\alpha$ ligand may modulate the inflammatory process through the regulation of the secretion of others cytokines, we analyzed the colon levels of proin-
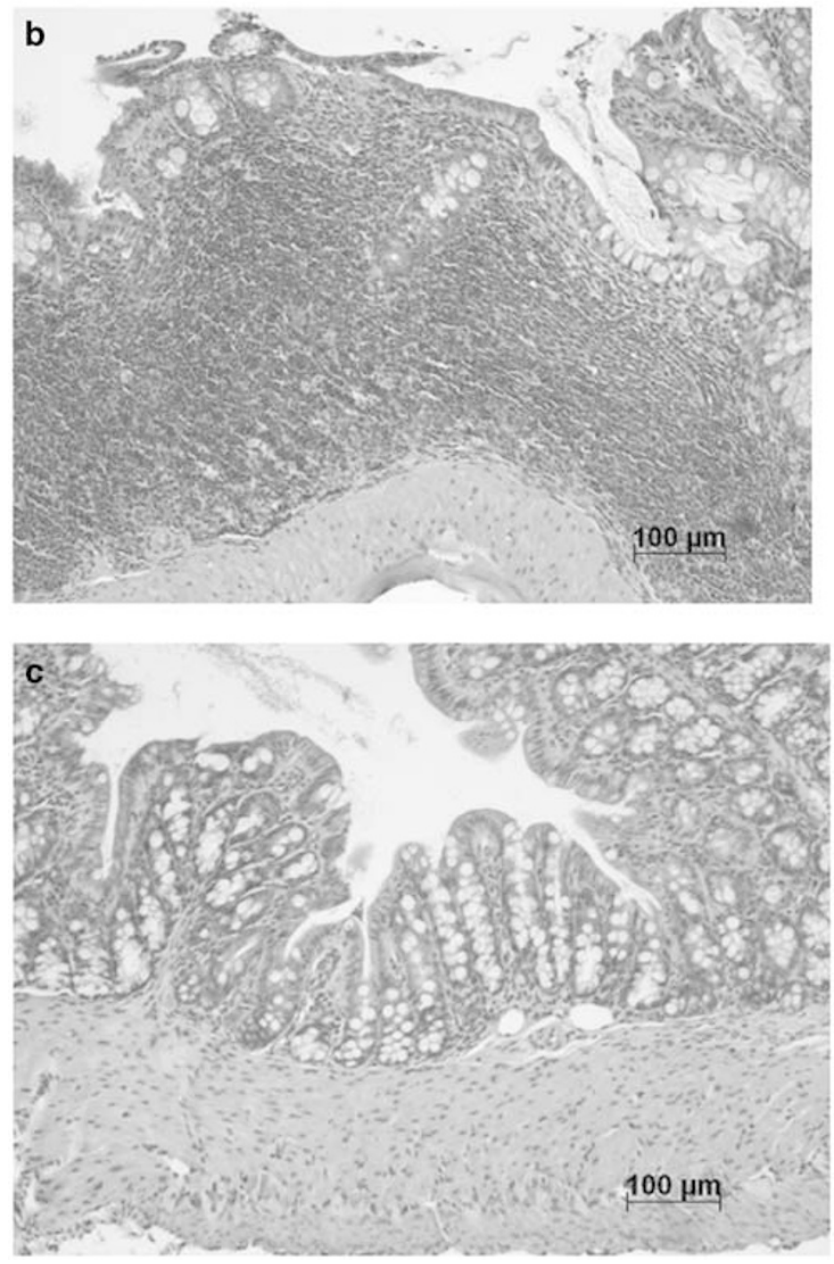

Figure 2 Effects of endogenous and exogenous PPAR- $\alpha$ ligand on colon injury. Mucosal injury was produced after DNBS administration characterized by the absence of epithelium and a massive mucosal and submucosal infiltration of inflammatory cells (a). The absence of PPAR- $\alpha$ gene significantly increases the extent and severity of the histological signs of colon injury (b). Treatment with Wy-14643 (1 mg/kg daily i.p.) (c) corrected the disturbances in morphology associated with DNBS administration. This figure is representative of at least three experiments performed on different experimental days. 

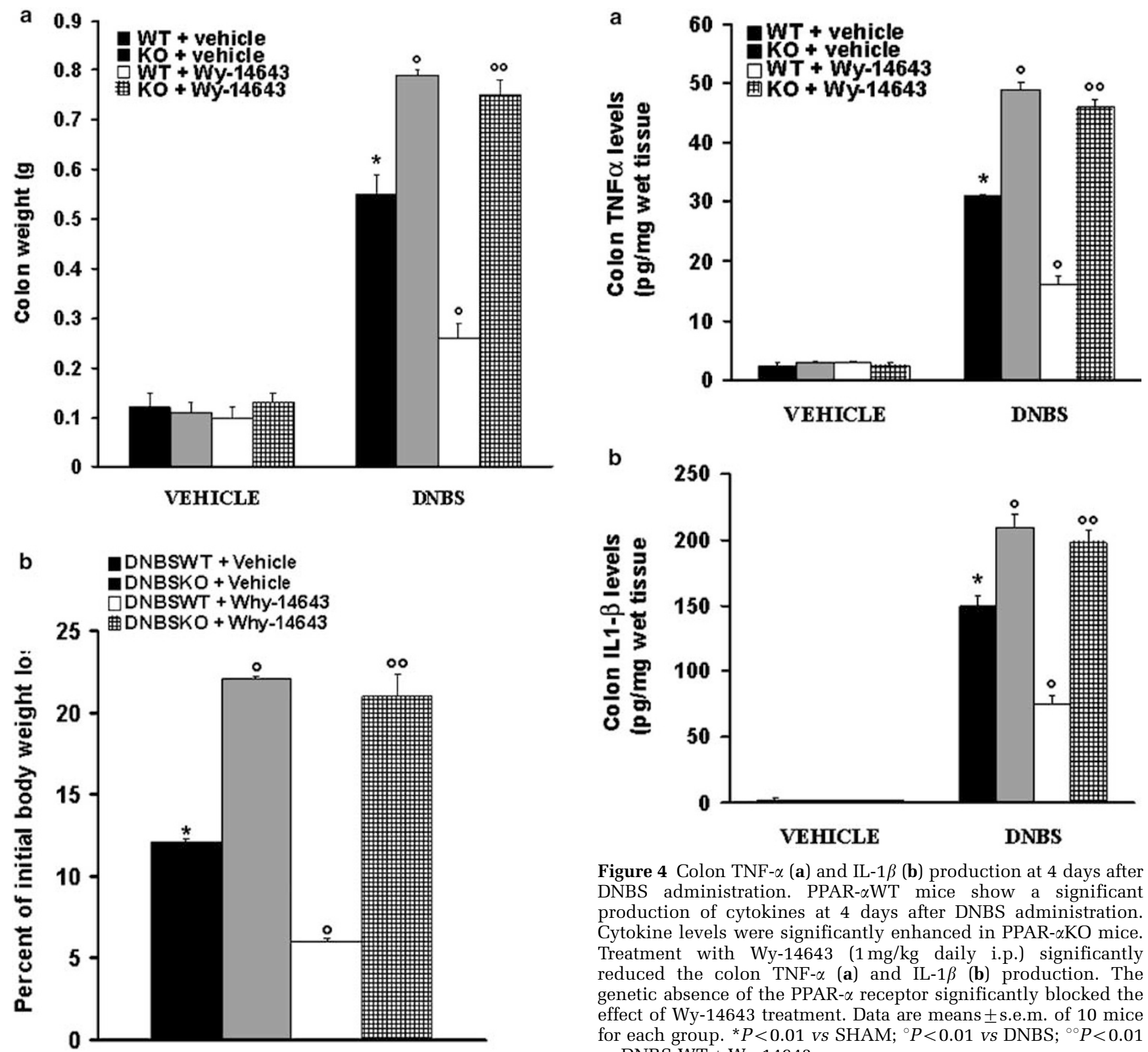

Figure 4 Colon TNF- $\alpha$ (a) and IL-1 $\beta$ (b) production at 4 days after DNBS administration. PPAR- $\alpha \mathrm{WT}$ mice show a significant production of cytokines at 4 days after DNBS administration. Cytokine levels were significantly enhanced in PPAR- $\alpha$ KO mice. Treatment with Wy-14643 (1 mg/kg daily i.p.) significantly reduced the colon TNF- $\alpha$ (a) and IL-1 $\beta$ (b) production. The genetic absence of the PPAR- $\alpha$ receptor significantly blocked the effect of Wy-14643 treatment. Data are means \pm s.e.m. of 10 mice for each group. ${ }^{*} \mathrm{P}<0.01$ vs SHAM; ${ }^{\circ} \mathrm{P}<0.01$ vs DNBS; ${ }^{\circ} \mathrm{P}<0.01$

Figure 3 Effect of endogenous and exogenous PPAR- $\alpha$ ligand on colon weight (a) and body weight changes (b) after DNBS intracolonic administration. At 4 days after DNBS administration a significant increase in the weight of the colon was observed (a) as well as a significant reduction in body weight increase (b). The absence of PPAR- $\alpha$ gene significantly increases the extent and severity of the colon weight (a) as well as the less body weight increase (b). Treatment with Wy-14643 (1 mg/kg daily i.p.) significantly reduced the colon weight and increase the body weight gain. The genetic absence of the PPAR- $\alpha$ receptor significantly blocked the effect of Wy-14643 treatment. Data are means \pm s.e.m. of 10 mice for each group. ${ }^{*} P<0.01$ vs SHAM; ${ }^{\circ} \mathrm{P}<0.01$ vs DNBS; ${ }^{\circ} \mathrm{P}<0.01$ vs DNBS-WT $+\mathrm{Wy}-14643$.

flammatory cytokines TNF- $\alpha$ in PPAR- $\alpha \mathrm{KO}$ and PPAR- $\alpha$ WT treated with Wy-14643. A substantial increase of TNF- $\alpha$ and IL- $1 \beta$ formation was found in colon samples collected from PPAR- $\alpha \mathrm{WT}$ mice at 4 days after DNBS administration (Figure 4). Colon

levels of TNF- $\alpha$ and IL- $1 \beta$ were significantly higher in PPAR- $\alpha$-deficient mice in comparison to those of PPAR- $\alpha$ WT animals (Figure 4). In contrast, a significant inhibition of TNF- $\alpha$ and IL- $1 \beta$ levels was observed in the colon tissues collected from PPAR$\alpha \mathrm{WT}$ treated with Wy-14643 (Figure 4). The genetic absence of the PPAR- $\alpha$ receptor significantly blocked the effect of the PPAR- $\alpha$ agonist on the production of proinflammatory cytokines (Figure 4). In addition, tissue sections obtained from PPAR- $\alpha \mathrm{WT}$ animals after DNBS administration demonstrate positive staining for TNF- $\alpha$ (Figures 5 a and 7 ) and for IL-1 $\beta$ (Figures 6a and 7) mainly localized in the infiltrated inflammatory cells in damaged mucosa (see particles 5A1 and 6A1 respectively). In DNBS-treated 

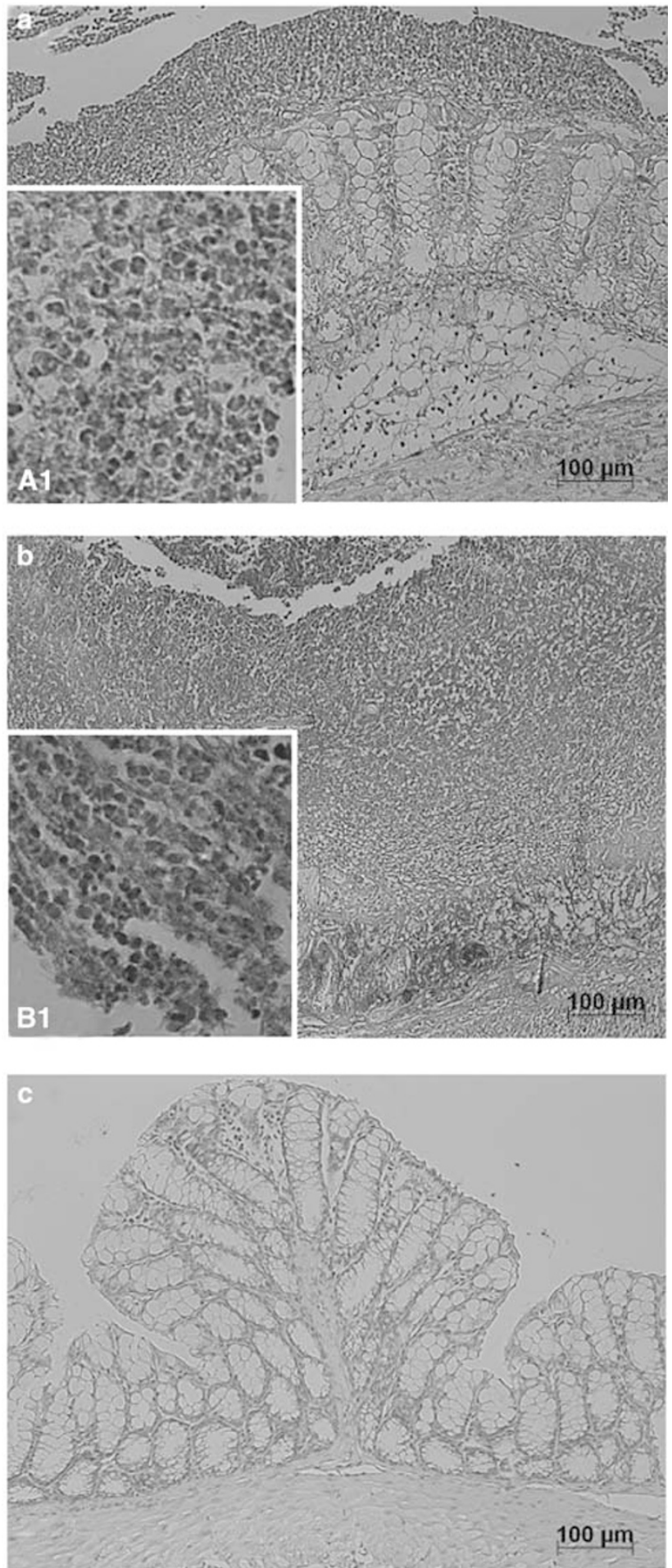

Figure 5 Immunohistochemical localization of $\mathrm{TNF}-\alpha$ in the colon. Immunohistochemical analysis for TNF- $\alpha$ (a) show positive staining localised in the inflammatory cells (see particle A1) in the injured area from DNBS-treated PPAR- $\alpha \mathrm{WT}$ mice. The intensity of the positive staining for TNF- $\alpha$ (b, see particle B1) was markedly increased in tissue section obtained from DNBStreated PPAR- $\alpha$ KO mice. No positive staining for TNF- $\alpha$ (c) was observed in tissue section obtained from $\mathrm{Wy}-14643(1 \mathrm{mg} / \mathrm{kg}$ daily i.p.)-treated PPAR- $\alpha \mathrm{WT}$ mice. This figure is representative of at least three experiments performed on different experimental days.
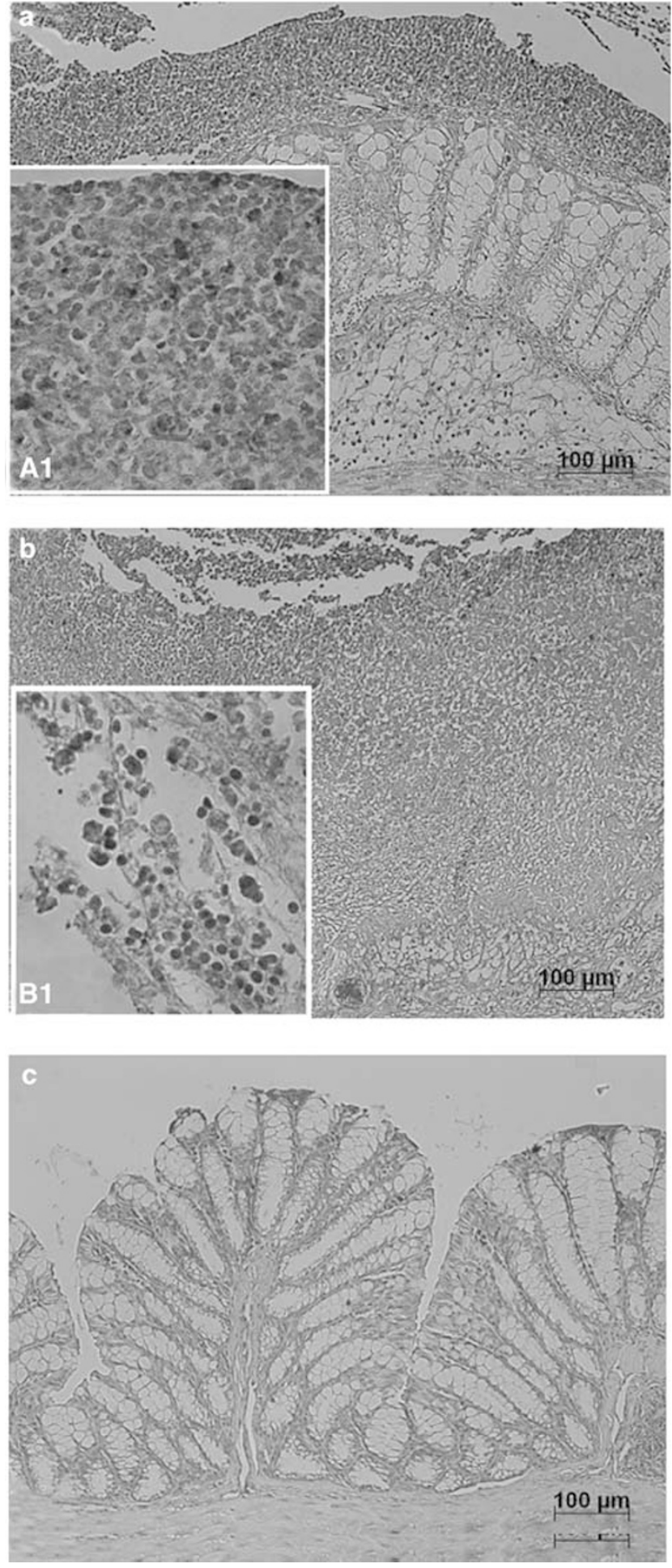

Figure 6 Immunohistochemical localization of IL- $1 \beta$ in the colon. Immunohistochemical analysis for IL-1 $\beta$ (a) show positive staining localized in the inflammatory cells (see particle A1) in the injured area from DNBS-treated PPAR- $\alpha \mathrm{WT}$ mice. The intensity of the positive staining for IL-1 $\beta$ (b, see particle B1) was markedly increased in tissue section obtained from DNBStreated PPAR- $\alpha$ KO mice. No positive staining for IL- $1 \beta$ (c) was observed in tissue section obtained from $\mathrm{Wy}_{\mathrm{y}}-14643(1 \mathrm{mg} / \mathrm{kg}$ daily i.p.)-treated PPAR- $\alpha \mathrm{WT}$ mice. This figure is representative of at least three experiments performed on different experimental days. 


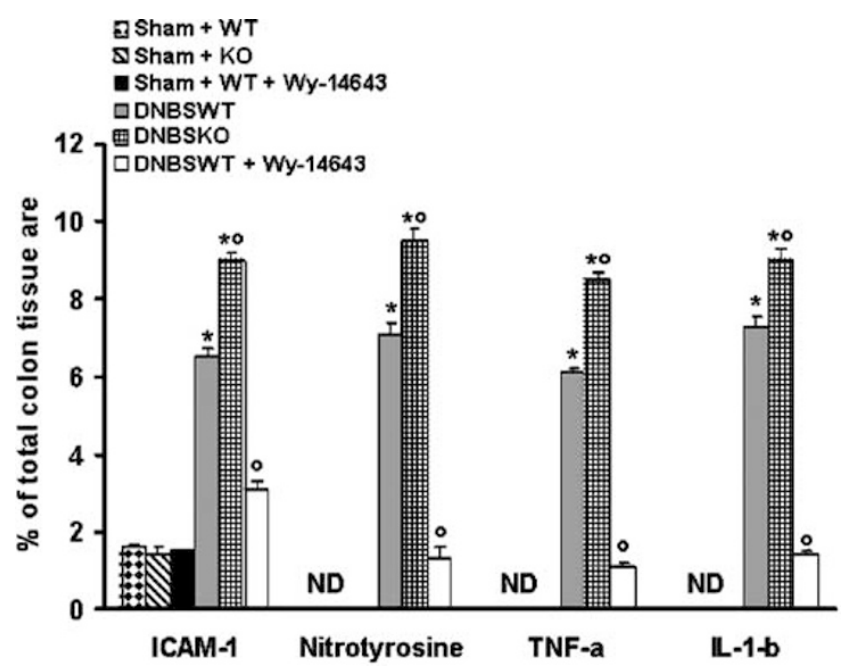

Figure 7 Effect of endogenous and exogenous PPAR- $\alpha$ ligand on neutrophil infiltration. Myeloperoxidase (MPO) activity was significantly increased in DNBS-treated PPAR- $\alpha \mathrm{WT}$ mice in comparison to SHAM. MPO activity was significantly enhanced in DNBS-treated PPAR- $\alpha$ KO mice. Treatment with Wy-14643 ( $1 \mathrm{mg} / \mathrm{kg}$ daily i.p) significantly reduced the colon MPO activity. The genetic absence of the PPAR- $\alpha$ receptor significantly blocked the effect of Wy-14643 treatment. Data are means \pm s.e.m. of 10 mice for each group. ${ }^{*} P<0.01$ vs SHAM; ${ }^{\circ} P<0.01$ vs DNBS; ${ }^{\circ} \mathrm{P}<0.01$ vs DNBS-WT $+\mathrm{Wy}-14643$.

PPAR- $\alpha$ KO mice, the staining for TNF- $\alpha$ (Figures $5 \mathrm{bB} 1$ and 7 ) and for IL-1 $\beta$ (Figures 6bB1 and 7) was visibly and significantly increased in comparison with the PPAR- $\alpha$ WT mice. Section from Wy-14643treated PPAR- $\alpha \mathrm{WT}$ mice did not reveal positive staining TNF- $\alpha$ (Figures $5 \mathrm{c}$ and 7 ) and for IL-1 $\beta$ (Figures 6c and 7). The genetic absence of the PPAR$\alpha$ receptor significantly blocked the effect of the PPAR- $\alpha$ agonist on the TNF- $\alpha$ and IL-1- $\beta$ expression (data not shown).

\section{Effects of Endogenous and Exogenous PPAR- $\alpha$ Ligand on ICAM-1 Expression and PMN Infiltration}

The colitis caused by DNBS was also characterized by an increase in myeloperoxidase activity, an indicator of the neutrophils accumulation in the colon (Figure 8). This finding is consistent with the observation made with light microscopy that the colon of vehicle-treated DBNS-rats contained a large number of neutrophils. In PPAR- $\alpha$ KO mice, colon myeloperoxidase activity was markedly increased in comparison to those of PPAR- $\alpha \mathrm{WT}$ animals (Figure 8). On the contrary, Wy-14643 significantly reduced the degree of PMN infiltration (determined as increase in MPO activity) in inflamed colon (Figure 8). The genetic absence of the PPAR- $\alpha$ receptor significantly blocked the effect of the PPAR- $\alpha$ agonist on the neutrophils infiltration (Figure 8). To further elucidate the effect of endogenous and exogenous PPAR- $\alpha$ ligand on neutrophils accumulation in

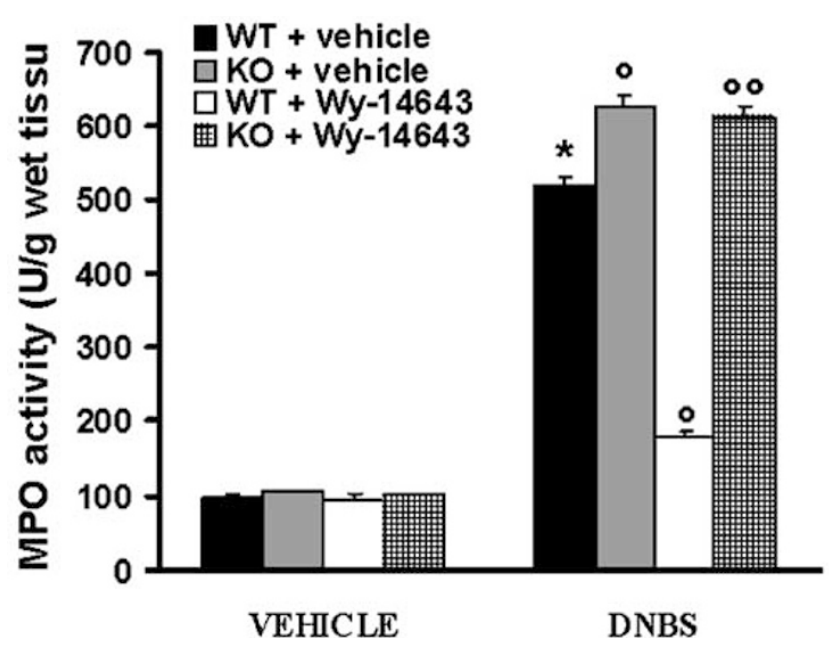

Figure 8 Typical densitometry evaluation. Densitometry analysis of immunocytochemistry photographs $(n=5)$ for ICAM-1 and nitrotyrosine from colon was assessed. The assay was carried out by using Optilab Graftek software on a Macintosh personal computer (CPU G3-266). Data are expressed as \% of total tissue area. ${ }^{*} P<0.01$ vs SHAM; ${ }^{\circ} P<0.01$ vs DNBS.

inflamed colon, we evaluated the intestinal expression of ICAM-1. Tissue sections obtained from sham-operated mice with anti-ICAM-1 antibody showed a specific staining along the vessels, demonstrating that ICAM-1 is expressed constitutively in endothelial cells (Figure 7). After DNBS administration, the staining intensity substantially increased in the vessels of the lamina propria and submucosa. Immunohistochemical staining for ICAM-1 was also present in epithelial cells of injured colon and in infiltrated inflammatory cells in damaged tissues from DNBS-treated PPAR- $\alpha \mathrm{WT}$ mice (Figures 7 and 9a). In DNBS-treated PPAR- $\alpha$ KO mice, the staining for ICAM-1 was visibly and significantly increased (Figures 7 and 9b) in comparison with the PPAR- $\alpha$ WT mice. Section from Wy14643-treated PPAR- $\alpha \mathrm{WT}$ mice did not reveal any upregulation of the constitutive ICAM-1, which was normally expressed in the endothelium along the vascular wall (Figures 7 and 9c). The genetic absence of the PPAR- $\alpha$ receptor significantly blocked the effect of the PPAR- $\alpha$ agonist on the ICAM-I expression (data not shown).

\section{Effects of Endogenous and Exogenous PPAR- $\alpha$ Ligand on Nitrotyrosine Formation}

To determine the localization of 'peroxynitrite formation' and/or other nitrogen derivatives produced during colitis, nitrotyrosine, a specific marker of nitrosative stress, was measured by immunohistochemical analysis in the distal colon. Sections of colon from sham-administered rats did not stain for nitrotyrosine (Figure 7). Colon sections obtained from vehicle-treated DNBS-PPAR- $\alpha \mathrm{WT}$ mice exhib- 

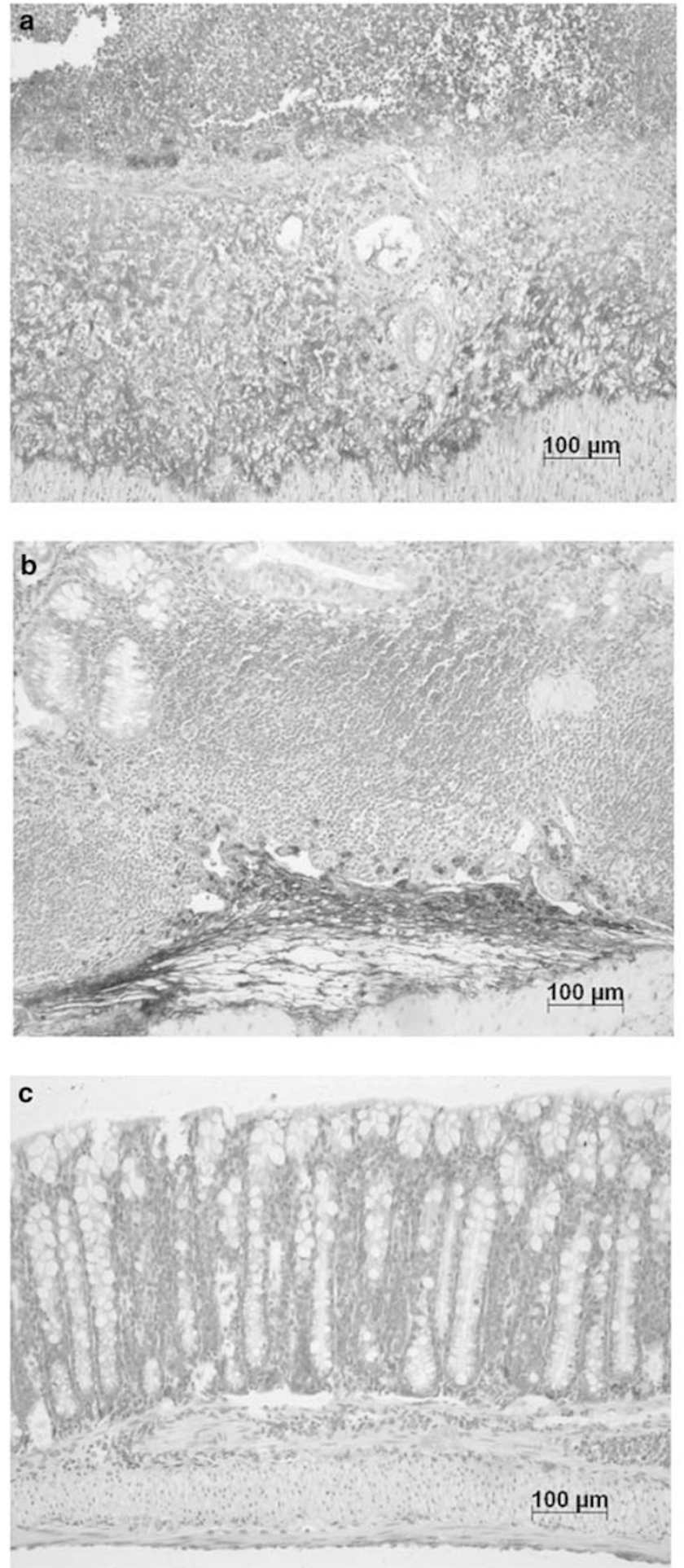

Figure 9 Immunohistochemical localization of ICAM-I in the colon. Section obtained from DNBS-treated PPAR- $\alpha$ WT mice showed intense positive staining for ICAM-1 (a) on endothelial cells. The degree of endothelial staining for ICAM-1 (b) was markedly increased in tissue section obtained from DNBS-treated PPAR- $\alpha$ KO mice (b). No positive endothelial staining for ICAM-1 (c) was observed in tissue section obtained from Wy-14643 $(1 \mathrm{mg} / \mathrm{kg}$ daily i.p.)-treated PPAR- $\alpha \mathrm{WT}$ mice. This figure is representative of at least three experiments performed on different experimental days.
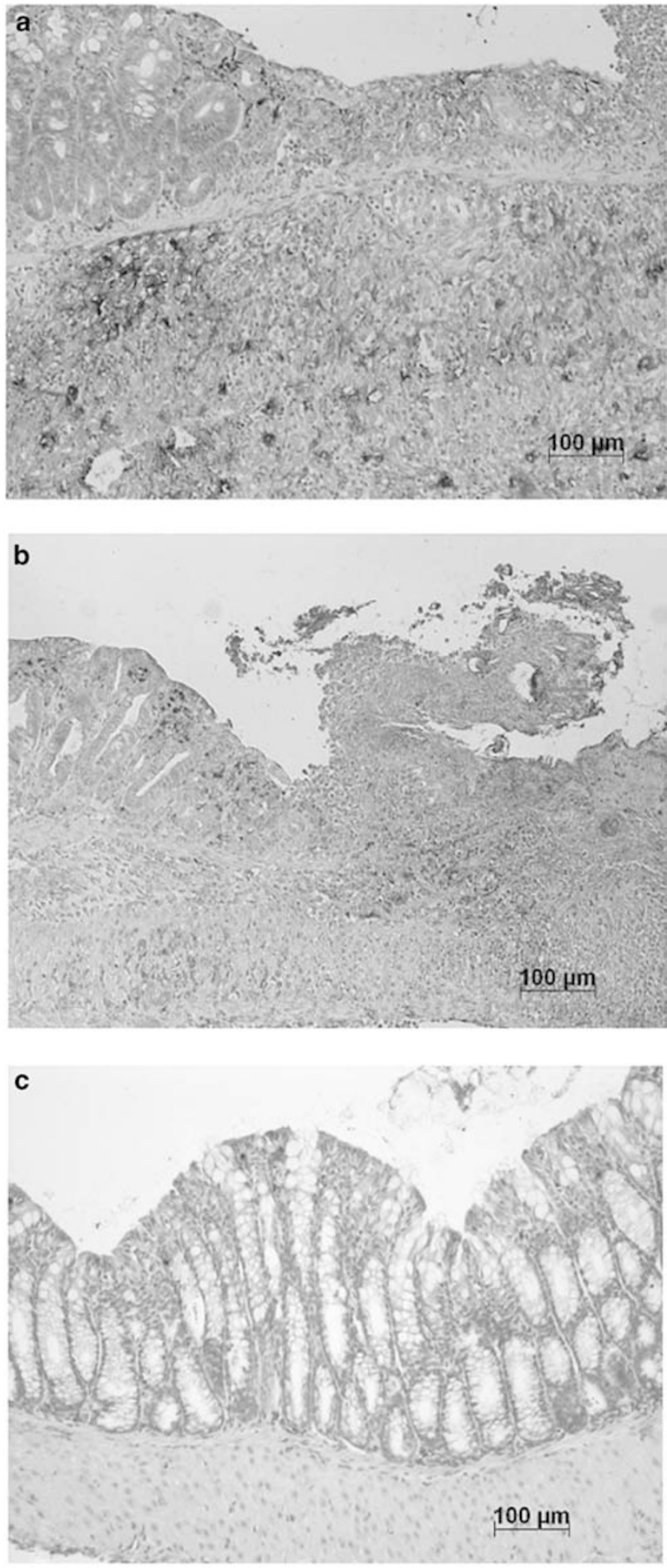

Figure 10 Immunohistochemical localization of nitrotyrosine in the colon. Immunohistochemical analysis for nitrotyrosine (a) show positive staining localized in the injured area from DNBStreated PPAR- $\alpha \mathrm{WT}$ mice. The intensity of the positive staining for nitrotyrosine (b) was markedly increased in tissue section obtained from DNBS-treated PPAR- $\alpha$ KO mice. No positive staining for nitrotyrosine (c) was observed in tissue section obtained from Wy-14643 (1 mg/kg daily i.p.)-treated PPAR- $\alpha$ WT mice. This figure is representative of at least three experiments performed on different experimental days. 
ited positive staining for nitrotyrosine (Figures 7 and 10a) localized in inflammatory cells and in disrupted epithelial cells. In DNBS-treated PPAR$\alpha \mathrm{KO}$ mice, the staining for nitrotyrosine was visibly and significantly increased (Figures 7 and 10b) in comparison with the PPAR- $\alpha$ WT mice. Section from Wy-14643-treated PPAR- $\alpha$ WT mice did not reveal any positive staining for nitrotyrosine (Figures 7 and 10c). The genetic absence of the PPAR $\alpha$ receptor significantly blocked the effect of the PPAR- $\alpha$ agonist on nitrotyrosine formation (data not shown).

\section{Discussion}

We demonstrate here that the absence of the PPAR- $\alpha$ gene significantly increase: (i) the degree of hemorrhagic diarrhea and weight loss, (ii) the degree of colonic injury, (iii) the infiltration of the colon PMNs, (iv) the positive staining (immunohistochemistry) for nitrotyrosine, as well as (v) the increased expression of ICAM-1 caused by DNBS in the colon. Furthermore, the treatment with Wy-14643, a potent exogenous PPAR- $\alpha$ ligand significantly reduced all the inflammatory parameters. All of these findings support the view that endogenous and exogenous PPAR- $\alpha$ ligand exerts potent anti-inflammatory effects and that PPAR- $\alpha$ ligand like $\mathrm{Wy}-14643$ may be useful in the therapy of IBD. What, then, is the mechanism by which PPAR- $\alpha$ ligand inhibit the colon inflammation caused by injection of DNBS?

Many PPAR- $\alpha$ ligands, including most of the common fibrate ligands, show only modest selectivity over the other PPAR subtypes. However, Wy14643 like GW7647 has been identified that shows excellent selectivity for both murine and human PPAR $-\alpha{ }^{33}$ PPAR- $\alpha$ is highly expressed in the liver, where it has initially been thought to regulate mainly genes involved in fatty acid $\beta$-oxidation. ${ }^{33}$ More recently, it has been demonstrated that PPAR- $\alpha$ is also expressed in the digestive tract mainly localized in the intestinal mucosa in the small intestine and in the colon. ${ }^{13-15}$ In particular, it has been demonstrated that there is a higher expression of PPAR in the more differentiated colonic epithelial cells facing the intestinal lumen as compared to cells in the lower parts of the crypts. ${ }^{13}$ Recently, it has been demonstrated that hepatic and duodenal PPAR- $\alpha$ expression is increased at the mRNA and protein levels in clofibrate-treated jerboa. ${ }^{34}$ Therefore, recent evidence has also pointed out that feeding a diet containing $\mathrm{Wy}-14643$ resulted in a large induction of peroxisomal HD mRNA in liver, reaching maximal level within a day. ${ }^{35,36}$ Intestinal fatty acid-binding protein mRNA was also gradually induced by $\mathrm{Wy}-14643$ and expressed only in the intestine. ${ }^{35}$

In addition, it has been demonstrated that PPAR- $\alpha$ activators suppress IL-1-induced C-reactive protein (CRP) and IL-6-induced fibrinogen expression, the major acute-phase response (APR) proteins in hu- mans ${ }^{37}$ whose plasma concentrations are elevated not only in acute but also in chronic inflammatory states. This anti-inflammatory action of PPAR- $\alpha$ is not restricted to these genes, but applies more generally to other APR genes, such as serum amyloid A (SAA) and fibrinogen-a and $-b .^{38}$ PPAR $\alpha$ activation leads to a reduction in the formation of nuclear $\mathrm{C} / \mathrm{EBPbBp} 50-\mathrm{NF}-\kappa \mathrm{B}$ complexes, and thereby reduces CRP promoter activation. Moreover, PPAR- $\alpha$ increases $\mathrm{I} \kappa \mathrm{Ba}$ expression, thus preventing nuclear p50/p65 NF- $\kappa \mathrm{B}$ translocation and arresting their nuclear transcriptional activity. Moreover, chronic treatment with fibrates decreases hepatic $\mathrm{C} / \mathrm{EBPb}$ and p50-NF- $\kappa$ B protein expression in mice in a PPAR- $\alpha$-dependent manner. ${ }^{38}$ This latter effect likely contributes to the generalized anti-inflammatory effects of fibrates on the expression of a wide range of APR genes containing response elements for these transcription factors in their promoters. NF- $\kappa \mathrm{B}$ activation induces the transcription of many proinflammatory genes, including TNF- $\alpha$, IL- $1 \beta$ and ICAM-1, to name but a few. ${ }^{39-43}$ We report in the present study here that endogenous and exogenous PPAR- $\alpha$ ligand reduces (among other effects) the biosynthesis and/or the effects of the proinflammatory cytokines TNF- $\alpha$ and IL-1 as well as the upregulation of ICAM-1. There is good evidence that TNF- $\alpha$ and IL- $1 \beta$, are clearly involved in the pathogenesis of colitis since these cytokines are present in colon tissues and can be detected immunohistochemically in the inflamed tissues. ${ }^{43,44}$ Direct evidence that TNF- $\alpha$ and IL- $1 \beta$ play a role in the pathogenesis of experimental colitis has been obtained in animal models in which blocking of the action of these cytokines has been shown to delay the onset of experimental colitis, suppress inflammation, and ameliorate colon destruction that corresponds to the anti-inflammatory response. ${ }^{45,46}$ A role for TNF- $\alpha$ in human disease came from recent studies using infliximab ${ }^{47-50}$ a chimeric anti-TNF antibody and CDP571 a humanized monoclonal antibody to TNF- $\alpha$ and membrane-bound TNF without fixing complement or mediating antibodydependent cellular cytotoxicity. ${ }^{51}$ In cases, significant reduction in Crohn's disease activity index (CDAI) as well as attenuation of attenuated histopathologic and endoscopic inflammation in Crohn's disease patients was observed. We confirm in the present study that the model of colitis used here leads to a substantial increase in the levels of TNF- $\alpha$ and IL-1 in the colon. Interestingly, the levels of these two proinflammatory cytokines are significantly higher in the absence of functional PPAR- $\alpha$ gene as well as are significantly lower in the PPARaWT mice, which were treated with Wy-14643. These findings, therefore, suggest that endogenous and exogenous PPAR- $\alpha$ ligand reduced the activation and the subsequent expression of pro-inflammatory genes. Neutrophils play a crucial role in the development and full manifestation of gastrointestinal inflammation, as they represent a major source 
of free radicals in the inflamed colonic mucosa. ${ }^{52,54}$ Neutrophil infiltration into inflamed tissue play a crucial role in the destruction of foreign antigens and in the breakdown and remodeling of injured tissue. ${ }^{51}$ The adhesion molecules ICAM-1, VCAM-1 and P-selectin play an important role in the recruitment of neutrophils into the inflamed colon. ${ }^{5,56}$ In this study as previously published, ${ }^{52,53}$ we demonstrate that the reduced expression of ICAM-1 will also result in reduced ROS formation associated to reduced infiltration of neutrophils into the colon. Thus, the reduction of the neutrophils infiltration by endogenous and exogenous PPAR- $\alpha$ ligand may contribute to the attenuation by these agents of the formation of nitrotyrosine, an indication of 'increased nitrosative stress', in the colon from DNBS-treated mice. Thus, we propose that the reduction of the neutrophils infiltration and ROS formation, caused by endogenous and exogenous $P P A R-\alpha$ ligand, contributes to the reduction by these agents of the organ injury caused by chronic inflammation in the mice. In conclusion, this study provides evidence that endogenous and exogenous PPAR- $\alpha$ ligand caused a substantial reduction of colon injury associated with experimental colitis in the mice. In addition, we also demonstrate, for the first time in vivo, that endogenous PPAR- $\alpha$ ligand, significantly attenuates the development of colon injury. Thus, we demonstrate here that the mechanisms underlying the protective effects of endogenous and exogenous PPAR- $\alpha$ ligand are dependent on the activation of PPAR- $\alpha$. The activation of PPAR- $\alpha$ by endogenous and exogenous ligands in turn, results in a reduction of (i) the nitration of proteins by peroxynitrite, (ii) the formation of the proinflammatory cytokines, (iii) the expression of the adhesion molecule ICAM-1. We speculate that ligands of PPAR- $\alpha$ may be useful in the therapy of conditions associated with inflammation.

\section{References}

1 Cuzzocrea S. Emerging biotherapies for inflammatory bowel disease. Expert Opin Emerg Drugs 2003;8: 339-347.

2 Elson CO. Experimental models of intestinal inflammation: new insights into mechanisms of mucosal homeostasis. In: Ogro PL, Lamm ME, Bienenstock J, Mestecky J, Strober W, McGhee JR (eds). Mucosal Immunmology. Academic Press: San Diego, CA, 1999, pp 1007-1024.

3 Snapper SB, Rosen FS, Mizoguchi E, et al. WiskottAldrich syndrome protein-deficient mice reveal a role for WASP in $\mathrm{T}$ but not $\mathrm{B}$ cell activation. Immunity 1998;9:81-91.

4 Matsumoto S, Okabe Y, Setoyama H, et al. Inflammatory bowel disease-like enteritis caecitis in a senescence accelerated mouse P1/Yit strain. Gut 1998; 43:71-78.

5 Blumberg RS, Saubermann LJ, Strober W. Animal models of mucosal inflammation and their relation to human inflammatory bowel disease. Curr Opin Immunol 1999;11:648-656.

6 Cuzzocrea S, McDonald MC, Mazzon E, et al. The tyrosine kinase inhibitor tyrphostin AG 126 reduced the development of colitis in the rat. Lab Invest 2000;80:1439-1453.

7 Mazzon E, Puzzolo D, Caputi AP, et al. Role of IL-10 in hepatocyte tight junction alteration in mouse model of experimental colitis. Mol Med 2002;8:353-366.

8 Evans RM. The steroid and thyroid hormone receptor superfamily. Science 1988;240:889-895.

9 Moras D, Gronemeyer H. The nuclear receptor ligandbinding domain: structure and function. Curr Opin Cell Biol 1998;10:384-391.

10 Murphy GJ, Holder JC. PPAR-gamma agonists: therapeutic role in diabetes, inflammation and cancer. Trends Pharmacol Sci 2000;21:469-474.

11 Desvergne B, Wahli W. Peroxisome proliferator-activated receptors: nuclear control of metabolism. Endocr Rev 1999;20:649-688.

12 Wayman NS, McDonald MC, Threadgill MD, et al. 5-Amino isoquinolinone, a potent inhibitor of poly (adenosine $5^{\prime}$-diphosphate ribose) polymerase, reduces myocardial infarct size. Eur J Pharmacol 2001;430: 93-100.

13 Mansen A, Guardiola-Diaz H, Rafter J, et al. Expression of the peroxisome proliferator-activated receptor (PPAR) in the mouse colonic mucosa. Biochem Biophys Res Commun 1996;222:844-851.

14 Escher P, Braissant O, Basu-Modak S, et al. Rat PPARs: quantitative analysis in adult rat tissues and regulation in fasting and refeeding. Endocrinology 2001;142: 4195-4202.

15 Huin C, Corriveau L, Bianchi A, et al. Differential expression of peroxisome proliferator-activated receptors (PPARs) in the developing human fetal digestive tract. J Histochem Cytochem 2000;48:603-611.

16 Sher T, Yi HF, McBride OW, et al. cDNA cloning, chromosomal mapping, and functional characterization of the human peroxisome proliferator activated receptor. Biochemistry 1993;32:5598-5604.

17 Ito $\mathrm{H}$, Nakano A, Kinoshita $\mathrm{M}$, et al. Pioglitazone, a peroxisome proliferator-activated receptor-gamma agonist, attenuates myocardial ischemia/reperfusion injury in a rat model. Lab Invest 2003;83:1715-1721.

18 Yue TL, Bao W, Jucker BM, et al. Activation of peroxisome proliferator-activated receptor-alpha protects the heart from ischemia/reperfusion injury. Circulation 2003;108:2393-2399.

19 Spiegelman BM. PPAR- $\gamma$ : adipogenic regulator and thiazolidinedione receptor. Diabetes 1998;47:507-514.

20 Murphy GJ, Holder JC. PPAR- $\gamma$ agonists: therapeutic role in diabetes, inflammation and cancer. Trends Pharmacol Sci 2000;21:469-474.

21 Lehmann JM, Lenhard JM, Oliver BB, et al. Peroxisome proliferator-activated receptors $\alpha$ and $\gamma$ are activated by indomethacin and other non-steroidal anti-inflammatory drugs. J Biol Chem 1997;272:3406-3410.

22 Young PW, Buckle DR, Cantello BC, et al. Identification of high-affinity binding sites for the insulin sensitizer rosiglitazone (BRL-49653) in rodent and human adipocytes using a radioiodinated ligand for peroxisomal proliferator-activated receptor $\gamma$. J Pharmacol Exp Ther 1998;284:751-759.

23 Willson TM, Brown PJ, Sternbach DD, et al. The PPARs: from orphan receptors to drug discovery. J Med Chem 2000;43:527-550. 
24 Su CG, Wen X, Bailey ST, et al. A novel therapy for colitis utilizing PPAR-gamma ligands to inhibit the epithelial inflammatory response. J Clin Invest 1999; 104:383-389.

25 Cuzzocrea S, Ianaro A, Wayman NS, et al. The cyclopentenone prostaglandin 15-deoxy-delta(12,14)PGJ2 attenuates the development of colon injury caused by dinitrobenzene sulphonic acid in the rat. Br J Pharmacol 2003;138:678-688.

26 Sturiale S, Barbara G, Qiu B, et al. Neutral endopeptidase (EC 3.4.24.11) terminates colitis by degrading substance P. Proc Natl Acad Sci USA 1999;96:11653-11658.

27 Lora L, Mazzon E, Billington D, et al. Effects of cyclosporin A on paracellular and transcellular transport of horseradish peroxidase in perfused rat livers. Dig Dis Sci 1997;42:514-521.

28 Wallace JL, Keenan CM, Gale D, et al. Exacerbation of experimental colitis by non-steroidal antinflammatory drugs is not related to elevate leukotriene B4 synthesis. Gastroenterology 1992;102:18-27.

29 Miller MJ, Thompson JH, Zhang XJ, et al. Role of inducible nitric oxide synthase expression and peroxynitrite formation in guinea pig ileitis. Gastroenterology 1995;109:1475-1483.

30 Zingarelli B, Squadrito F, Graziani P, et al. Effects of zileuton, a new 5-lipoxygenase inhibitor, in experimentally induced colitis in rats. Agents Actions 1993;39:150-156.

31 Mullane KM, Kraemer R, Smith B. Myeloperoxidase activity as a quantitative assessment of neutrophil infiltration into ischemic myocardium. J Pharmacol Methods 1985;14:157-167.

32 Diaz-Granados N, Howe K, Lu J, et al. Dextran sulfate sodium-induced colonic histopathology, but not altered epithelial ion transport, is reduced by inhibition of phosphodiesterase activity. Am J Pathol 2000;156: 2169-2177.

33 Jackson TA, Richer JK, Bain DL, et al. The partial agonist activity of antagonist-occupied steroid receptors is controlled by a novel hinge domain-binding coactivator L7/SPA and the corepressors N-CoR or SMRT. Mol Endocrinol 1997;11:693-705.

34 Amsaguine-Safir S, Bianchi A, Collet P, et al. Induction of the expression of the peroxisome proliferatoractivated receptor alpha (PPARalpha) by clofibrate in jerboa tissues. Microsc Res Techn 2003;61:185-190.

35 Motojima K, Passilly P, Peters JM, et al. Expression of putative fatty acid transporter genes are regulated by peroxisome proliferator-activated receptor a and $\mathrm{g}$ activators in a tissue- and inducer-specific manner. J Biol Chem 1998;27:16710-16714.

36 Motojima K, Goto S, Imanaka T. Specific repression of transthyretin gene expression in rat liver by a peroxisome proliferator clofibrate. Biochem Biophys Res Commun 1992;188:799-806.

37 Kleemann R, Gervois PP, Verschuren L, et al. Fibrates down-regulate IL-1-stimulated C-reactive protein gene expression in hepatocytes by reducing nuclear p50NFkappa B-C/EBP-beta complex formation. Blood 2003;101:545-551.

38 Gervois P, Vu-Dac N, Kleemann R, et al. Negative regulation of human fibrinogen gene expression by peroxisome proliferator-activated receptor alpha agonists via inhibition of CCAAT box/enhancer-binding protein beta. J Biol Chem 2001;276:33471-33477.

39 Izumi T, Saito Y, Kishimoto I, et al. Blockade of the natriuretic peptide receptor guanylyl cyclase-A inhibits NF-kappaB activation and alleviates myocardial ischemia/reperfusion injury. J Clin Invest 2001; 108:203-213.

40 Manning AM, Bell FP, Rosenbloom CL, et al. NF-kappa $\mathrm{B}$ is activated during acute inflammation in vivo in association with elevated endothelial cell adhesion molecule gene expression and leukocyte recruitment. J Inflamm 1995;45:283-296.

41 Telek G, Ducroc R, Scoazec JY, et al. Differential upregulation of cellular adhesion molecules at the sites of oxidative stress in experimental acute pancreatitis. J Surg Res 2001;96:56-67.

42 Guy GR, Chua SP, Wong NS, et al. Interleukin 1 and tumor necrosis factor activate common multiple protein kinases in human fibroblasts. J Biol Chem 1991;266:14343-14352.

43 Carty E, De Brabande M, Feakins RM, et al. Measurement of in vivo rectal mucosal cytokine and eicosanoid production in ulcerative colitis using filter paper. Gut 2000;46:487-492.

44 Negoro K, Kinouchi Y, Hiwatashi N, et al. Crohn's disease is associated with novel polymorphisms in the 5 -flanking region of the tumor necrosis factor gene. Gastroenterology 1999;117:1062-1068.

45 Andborn WJ, Hanauer SB. Antitumor necrosis factor therapy for inflammatory bowel disease: a review of agents, pharmacology, clinical results, and safety. Inflamm Bowel Dis 1999;2:119-133.

46 Urthy S, Cooper HS, Yoshitake H, et al. Combination therapy of pentoxifylline and TNF- $\alpha$ monoclonal antibody in dextran sulphate-induced mouse colitis. Aliment Pharmacol Ther 1999;13:251-260.

47 Present DH, Rutgeerts P, Targan S, et al. Infliximab for the treatment of fistulas in patients with Crohn's disease. N Engl J Med 1999;340:1398-1405.

48 Ricart E, Panaccione R, Loftus EV, et al. Successful management of Crohn's disease of the ileoanal pouch with infliximab. Gastroenterology 1999;117:429-432.

49 D’Haens G, Geboes K, Rutgeerts P, et al. Endoscopic and histological healing with infliximab anti-tumor necrosis factor antibodies in Crohn's disease: a European multicenter trial. Gastroenterology 1999; 116: 1029-1034.

50 Baert FJ, D’Haens GR, Peeters M, et al. Tumor necrosis factor alpha antibody (infliximab) therapy profoundly down-regulates the inflammation in Crohn's ileocolitis. Gastroenterology 1999;116:22-28.

51 Stack WA, Mann SD, Roy AJ, et al. Randomized controlled trial of CDP571 antibody to tumor necrosis factor-alpha in Crohn's disease. Lancet 1997;349: 521-524.

52 Shiratora Y, Aoki S, Takada H, et al. Oxygen-derived free radical generating capacity of polymorphonuclear cells in patients with ulcerative colitis. Digestion 1989;44:163-171.

53 Grisham MB. Oxidants and free radicals in inflammatory bowel disease. Lancet 1994;344:859-861.

54 Lefer AM, Lefer DJ. Pharmacology of the endothelium in ischemia-reperfusion and circulatory shock. Annu Rev Pharmacol Toxicol 1993;33:71-90.

55 Cuzzocrea S, Mazzon E, Dugo L, et al. Protective effects of M40403, a superoxide dismutase mimetic, in a rodent model of colitis. Eur J Pharmacol 2001;432: 79-89.

56 Cuzzocrea S, McDonald MC, Mazzon E, et al. Calpain inhibitor I reduces colon injury caused by dinitrobenzene sulphonic acid in the rat. Gut 2001;48:478-488. 